\title{
Partial characterization of digestive proteases in sheepshead, Archosargus probatocephalus (Spariformes: Sparidae)
}

\author{
María L. Merino-Contreras ${ }^{1,2}$, Froylán Sánchez-Morales², María L. Jiménez-Badillo, \\ Emyr S. Peña-Marín ${ }^{3,4}$, Carlos A. Álvarez-González ${ }^{3}$
}

Digestive proteases were partially characterized in sheepshead juveniles, using biochemical and electrophoretic techniques. Results showed higher activity level of the stomach proteases $\left(2.39 \pm 0.02 \mathrm{U} \mathrm{mg}\right.$ protein $\left.{ }^{-1}\right)$ compared to the intestinal proteases $\left(1.6 \pm 0.1 \mathrm{U} \mathrm{mg}\right.$ protein $\left.{ }^{-1}\right)$. The activity of trypsin, chymotrypsin, leucine aminopeptidase and carboxypeptidase A was also recorded. The optimum temperature of the stomach proteases was recorded at $45^{\circ} \mathrm{C}$, while for intestinal proteases was recorded at $55^{\circ} \mathrm{C}$. Stomach proteases showed less stability to temperature changes than intestinal proteases. An optimum pH of 2 was recorded for stomach proteases with high stability under acidic conditions, while an optimum $\mathrm{pH}$ of 9 was recorded for intestinal proteases showing high stability under alkaline conditions. Stomach proteases were inhibited around $78 \%$ with Pepstatin $\mathrm{A}$, indicating the presence of pepsin as the main protease. The stomach proteases zymogam revealed one active band with $\mathrm{Rf}$ of 0.49 , this enzyme was completely inhibited by Pepstatin A. The intestinal proteases zymogram revealed four active proteases $(51.3,34.9,27.8$ and $21.2 \mathrm{kDa})$ that were inhibited by TLCK, which mainly represent a trypsin-like serine proteases. It can be conclude that digestion in sheepshead can be considered as a carnivorous species with an omnivorous tendency.

Keywords: Aquaculture, Inhibitors, Pepsin, Proteases, Zymogram

Se caracterizaron parcialmente las proteasas digestivas de juveniles del sargo, utilizando técnicas bioquímicas y electroforéticas. Los resultados muestran mayores niveles de actividad en las proteasas estomacales $\left(2.39 \pm 0.02 \mathrm{U} \mathrm{mg} \mathrm{proteina}^{-1}\right)$ comparados con los de las proteasas intestinales $\left(1.6 \pm 0.1 \mathrm{U} \mathrm{mg}\right.$ protein $\left.{ }^{-1}\right)$, también se registró la actividad de tripsina, quimotripsina, leucina aminopeptidasa y carboxipeptidasa $\mathrm{A}$. La temperatura óptima de las proteasas estomacales fue de $45^{\circ} \mathrm{C}$, mientras que la de las proteasas intestinales fue de $55^{\circ} \mathrm{C}$. El pH óptimo fue de 2 para las proteasas estomacales con alta estabilidad a condiciones ácidas, mientras que el pH óptimo para las proteasas intestinales fue de 9 , mostrando una alta estabilidad en condiciones alcalinas. Las actividades de las proteasas estomacales fue inhibida en un $78 \%$ con Pepstatina A, lo que indica la presencia de pepsina, como principal proteasa. El zimograma de proteasas estomacales reveló una sola banda con actividad proteasa, con Rf de 0.49, completamente inhibida por Pepstatina A. El zimograma de proteasas intestinales reveló cuatro bandas $(51.3,34.9,27.8$ y $21.2 \mathrm{kDa})$. Todas las bandas se inhibieron con TLCK, lo que muestra la presencia principalmente de serina proteasas tipo tripsina. Se concluye que la digestión del sargo puede ser considerada como la de una especie carnívora con tendencia al omnivorismo.

Palabras Clave: Acuicultura, Inhibietores, Pepsina, Proteasas, Zymograma

\section{Introduction}

The sheepshead fish, Archosargus probatocephalus (Walbaum, 1792), is a coastal, subtropical marine fish that regularly enters brackish waters. This species is an important component of the commercial and recreational-sport fisheries along the Atlantic coast of the US and the Gulf of Mexico (Figueira, Coleman, 2010; McDonough et al., 2011), and has recently been considered viable for the development of mariculture in the southeast Mexican region (RNIIPA, 2012).

\footnotetext{
${ }^{1}$ Instituto de Ciencias Marinas y Pesquerías, Universidad Veracruzana. Calle Hidalgo 617, Col. Río Jamapa, 94290 Boca del Río, Veracruz, Mexico. (MLMC) madelaluz.merino020@gmail.com, (MLJB) ljimenez@uv.mx

${ }^{2}$ Laboratorio de Acuicultura, Instituto Tecnológico de Boca del Río. Departamento de Ciencias del mar. Carretera Federal Veracruz-Cordoba km 12, 94290 Boca del Rio, Veracruz, Mexico. (FSM) komodosanchez@yahoo.com.mx

${ }^{3}$ Laboratorio de Acuicultura Tropical DACBiol, Universidad Juárez Autónoma de Tabasco. Km. 0.5 carretera Villahermosa-Cárdenas entronque Bosques de Saloya, 86039 Villahermosa, Tabasco, Mexico. (CAAG) alvarez_alfonso@hotmail.com, Dhttps://orcid.org/00000001-9240-0041 (corresponding author)

${ }^{4}$ Consejo Nacional de Ciencia y Tecnología. Av. Insurgentes Sur 1582, Col. Crédito Constructor, Del. Benito Juárez, 03940 Ciudad de México, Mexico. (ESPM) ocemyr@yahoo.com.mx
} 
Tucker $(1998,2004)$ describes the species with aquaculture potential since it has great adaptability to captivity, a wide range of feeding sources, adapts easily to high density conditions and has been induced to spawn, allowing the production of juveniles under laboratory conditions. However, in order to achieve commercial scale cultivation it is necessary to understand the basic nutritional aspects that allow the development of balanced foods at the lowest possible cost. Therefore, it is of great importance to study digestive physiological processes in which digestive enzymes are vital to the effective hydrolysis of nutrients during digestion (Scocco et al., 1997; Olsson, Holmgren, 2001). The sheepshead demonstrates an omnivorous trophic strategy, an unusual behaviour between sparids that generally tends to be carnivorous, and an ability to change from a carnivorous habit to an omnivorous or herbivorous habit during their development (Patillo et al., 1997). Early juvenile sheepsheads have been previously reported to develop carnivorous habits when they grow to a length of around $50 \mathrm{~mm}$ (GSMFC, 2006), whilst the adults are considered omnivorous since they mainly feed on algae and invertebrates (Jobling, 1995; Cutwa, Turingan, 2000; Castillo-Rivera et al., 2007).

Hence, studies of digestive physiology are necessary for the development of a specific diet formulation, to determine the amount and the type of ingredients to be incorporated into the diet, which depends on the enzymatic activity present in the digestive system, particularly in the case of proteases, since protein is the most important nutrient in relation to energy and amino acid requirements in fish (Lazo et al., 2007). In fish, the digestion process involves several enzymes that are responsible for protein hydrolysis (Eroldogan et al., 2008), where the activity expressed depends on several factors such as the feeding habits, food type, among other (Kuz'mina, Strel'nikova, 2008). In this way, the characterization of digestive proteases allows the determination of the optimal conditions for enzymes to reach their maximum activity as well as stability at different temperature and pH conditions (Simpson, 2000), in addition to the effect of inhibitors on protease activity (Falcon- Hidalgo et al., 2011; Unajak et al., 2012). Likewise, characterization of digestive enzymes shows the effect of physicochemical conditions, which let us to understand the kinetic mechanism of the enzymes in the species of interest (García-Carreño et al., 1993; Klomklao et al., 2008; Álvarez-González et al., 2010).

Considering the above mentioned, digestive protease characterization studies have been carried out for many years in different species of marine fish such as: gilthead seabream Sparus aurata, Atlantic bluefin tuna Thunnus thynnus (Linnaeus, 1758), Asian bony tongue Scleropages formosus (Müller \& Schlegel, 1840), Monterey sardine Sardinops sagax (Jenyns, 1842), Senegalese sole Solea senegalensis Kaup, 1858, turbot Scophthalmus maximus (Linnaeus, 1758), Pacific bluefin tuna Thunnus orientalis (Temminck \& Schlegel, 1844), Albacore tuna Thunnus alalunga (Bonnaterre, 1788), spotted rose snapper Lutjanus guttatus (Steindachner, 1869) and common snook Centropomus undecimalis (Bloch,
1792) (Alarcón et al., 2001; Essed et al., 2002; Natalia et al., 2004; Castillo-Yañez et al., 2005; Sáenz -de Rodrigáñez et al., 2005; Wang et al., 2006; Matus-De la Parra et al., 2007; Nalinanon et al., 2010a; Peña et al., 2015; Concha-Frías et al., 2016). In these studies it has been shown that acidic proteases commonly present an optimal activity between $\mathrm{pH} 2$ and 3 and optimal temperatures between 35 and $65^{\circ} \mathrm{C}$. On the other hand, most of the alkaline proteases maintain an optimum $\mathrm{pH}$ between 9 and 10, and an optimal temperature of between 45 and $65{ }^{\circ} \mathrm{C}$. In relation to inhibitors, in some carnivorous species the activity of acid proteases is totally inhibited by Pepstatin A, which represents pepsin-like type activity. In contrast, the inhibition of alkaline proteases is variable among species, as they are influenced by the environment and feeding habits (Díaz-López et al., 1998; Kuz mina et al., 2008; Falcon-Hidalgo et al., 2011).

Some reports in certain fish species indicate that, changes in specific enzyme activity vary at different ages (Chiu, Pan, 2006; Falcon-Hidalgo et al., 2011; Peña et al., 2015). Therefore, the objective of this work is to partially characterize the digestive proteases of juvenile sheepshead (A. probatocephalus), to provide basic information on the digestive physiology, the optimal conditions, stability and mechanisms of action of these enzymes, since in this species is still unknown, which will provide a basis for the elaboration of practical diets that allows adequate growth in culture.

\section{Material and methods}

Preparation of enzymatic extracts. Enzymatic extracts were prepared from five wild sheepshead (Archosargus probatocephalus, voucher ECOSC 13593, four specimens) juveniles $(100 \pm 10 \mathrm{~g})$, captured from the lagoon of Alvarado, Veracruz, Mexico. The fish were starved for 24 hours and sacrificed by thermic shock using ice water. The weight was recorded in each organism with an Ohaus ${ }^{\circledR}$ digital balance $(0.01 \mathrm{~g}$, Shenzhen, China), and total length with an ichthyometer. Extraction of stomach and intestine was performed under cold conditions $\left(4{ }^{\circ} \mathrm{C}\right)$, registering the weight of each organ, which were then frozen and lyophilized. Subsequently each organ was homogenized separately in a ratio of 1:30 (weight: buffer volume) and homogenized with an IKA (MCA T18 basic Ultraturrax) tissue homogenizer. The stomachs were homogenized in $100 \mathrm{mmol} \mathrm{L}^{-1}$ glycine- $\mathrm{HCl}$ buffer at $\mathrm{pH} 2$ and the intestines were homogenized in 30 mmol L-1 Tris- $\mathrm{HCl}+12.5 \mathrm{mmol} \mathrm{L}^{-1} \mathrm{CaCl}_{2}$ buffer at $\mathrm{pH} 7.5$, the enzymatic extracts of the specimens were processed individually. The homogenates were centrifuged at $14,000 \mathrm{~g}$ for $30 \mathrm{~min}$ at $4{ }^{\circ} \mathrm{C}$, and the supernatants were stored at -80 ${ }^{\circ} \mathrm{C}$ until analysis. The concentration of soluble protein in the enzymatic extracts of stomach and intestine was determined with the technique described by Bradford (1976). All tests were performed in triplicate.

Protease activity analysis. Acidic protease activity was determined using the technique described by Anson (1938), 
using bovine hemoglobin $1 \%$ as a subtrate in $100 \mathrm{mmol} \mathrm{L}^{-1}$ glycine- $\mathrm{HCl}$ buffer at $\mathrm{pH} 2$. The alkaline protease activity was determined using the technique described by Kunitz (1947) modified by Walter (1984), using casein $1 \%$ as a substrate in $100 \mathrm{mmol} \mathrm{L}^{-1}$ Tris- $\mathrm{HCl}, 10 \mathrm{mmol} \mathrm{L}^{-1} \mathrm{CaCl}_{2}$ buffer at $\mathrm{pH}$ 9. One unit (U) of enzymatic activity was defined as the amount of enzyme that produced $1 \mu \mathrm{mol}$ of product (tyrosin liberated) per minute. The hydrolysis of haemoglobin and casein was determined at $280 \mathrm{~nm}$, the molar extinc-

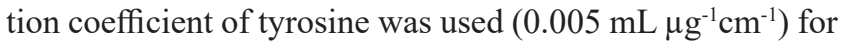
both proteases. The trypsin activity was determined with the method described by Erlanger et al. (1961), using $1 \mathrm{mmol}$ $\mathrm{L}^{-1}$ of N $\alpha$-Benzoyl-DL-arginine-4-nitroanilide hydrochloride (BAPNA) as a substrate in $100 \mathrm{mmol} \mathrm{L}^{-1}$ Tris- $\mathrm{HCl}, 10$ mmol L-1 $\mathrm{CaCl}_{2}$ buffer at $\mathrm{pH} 8$, one unit (U) of enzymatic activity was defined as the amount of enzyme that produced $1 \mu \mathrm{mol}$ of p-nitroaniline per minute, using a molar extinction coefficient of $8.8 \mathrm{~mL} \mu \mathrm{mol}^{-1} \mathrm{~cm}^{-1}$. Chymotrypsin activity was measured as described by Del Mar et al. (1979), a technique using $0.1 \mathrm{mmol} \mathrm{L}^{-1}$ of SAAPNA (N-succinyl-ala-ala-pro-phe p-nitroanilide) as a substrate in $100 \mathrm{mmol} \mathrm{L}^{-1}$ Tris- $\mathrm{HCl}, 10 \mathrm{mmol} \mathrm{L}^{-1} \mathrm{CaCl}_{2}$ buffer at $\mathrm{pH} 7.8$, one unit (U) of enzymatic activity was defined as the amount of enzyme that produced $1 \mu \mathrm{mol}$ of $\mathrm{p}$-nitroanilide liberated per minute, using a molar extinction coefficient of $0.906 \mathrm{~mL} \mu \mathrm{mol}^{-1} \mathrm{~cm}^{-1}$. The activity of leucine-aminopeptidase was measured with the technique described by Maroux et al. (1973), using 1 mmol L-1 of leucine p-nitroanilide as substrate in $50 \mathrm{mmol}$ $\mathrm{L}^{-1}$ monobasic sodium phosphate buffer at $\mathrm{pH} 7.2$, one unit (U) of enzymatic activity was defined as the amount of enzyme that produced $1 \mu \mathrm{mol}$ of alanine $\mathrm{p}$-nitroaniline liberated per minute, with molar extinction coefficient of $8.2 \mathrm{~mL}$ $\mu \mathrm{mol}^{-1} \mathrm{~cm}^{-1}$. The carboxypeptidase A activity was measured with the technique described by Folk and Schirmer (1963), using $1 \mathrm{mmol} \mathrm{L}^{-1}$ of hipuryl-L-phenylalanine as a substrate in $25 \mathrm{mmol} \mathrm{L}^{-1}$ Tris- $\mathrm{HCl}, 50 \mathrm{mmol} \mathrm{L}^{-1} \mathrm{NaCl}$ buffer at $\mathrm{pH} 7.5$ solution, one unit $(\mathrm{U})$ of enzymatic activity was defined as the amount of enzyme that produced $1 \mu \mathrm{mol}$ of hippuric acid per minute, using molar extinction coefficient of $0.36 \mathrm{~mL}$ $\mu \mathrm{mol}^{-1} \mathrm{~cm}^{-1}$. All tests were performed in triplicate. Total activity $\left(\right.$ Units $\left.\mathrm{mL}^{-1}\right)=[\Delta$ abs*reaction final volume $(\mathrm{mL})] /[\mathrm{ME}-$ $\mathrm{C}^{*}$ time $(\mathrm{min}) *$ extract volume $\left.(\mathrm{mL})\right]$. Specific activity (Units mg $\left.\operatorname{prot}^{-1}\right)=$ Total activity/soluble protein $(\mathrm{mg})$, where $\Delta$ abs represent the increase in absorbance, and MEC represents the respective molar extinction coefficient.

Effect of $\mathrm{pH}$ and temperature on digestive proteases. The optimum $\mathrm{pH}$ of the acidic and alkaline proteases was observed within the range of 2 to 12 , using the universal solution of Stauffer (1989), substituted in the technique of Anson (1938) and Walter (1984) respectively. For pH stability, enzyme extracts were preincubated $\left(25^{\circ} \mathrm{C}\right)$ at different $\mathrm{pH}$ 's at time intervals of $0,30,60$ and $90 \mathrm{~min}$. The optimal temperature of the acidic and alkaline proteases was determined by modifying the incubation temperature within a range of 25 to $65{ }^{\circ} \mathrm{C}$ with intervals of $10{ }^{\circ} \mathrm{C}$, in the techniques des- cribed by Anson (1938) and Walter (1984) respectively. To determine the stability of the proteases during temperature changes, the enzyme extracts were preincubated at the different temperatures mentioned above for 0, 30, 60 and $90 \mathrm{~min}$, where the time 0 min (without pre-incubation) was used as a control to determine the residual activity expressed as a percentage. All tests were performed in triplicate.

Effect of inhibitors on protease activity. The sensitivity of the protease activity was determined using specific inhibitors: $1 \mathrm{mmol} \mathrm{L}^{-1}$ of Pepstatin A inhibitor was used for the acid proteases, and its residual activity was determined with the Anson (1938) technique as previously described. For the alkaline proteases, the specific inhibitors were used as described by García-Carreño et al. (1993): $5 \mathrm{mmol} \mathrm{L}^{-1}$ tosyl-phenylanyl-chloromethyl ketone (TPCK), $10 \mathrm{mmol} \mathrm{L}^{-1}$ phenanthroline (PHE), $10 \mathrm{mmol} \mathrm{L}^{-1}$ ethyl-diamine tetra-acetic acid (EDTA), $10 \mathrm{mmol} \mathrm{L}^{-1}$ tosyl-lysyl-chloromethyl ketone (TLCK), $250 \mathrm{mmol} \mathrm{L}^{-1}$ soybean trypsin inhibitor (SBT1), $100 \mathrm{mmol} \mathrm{L}^{-1}$ phenyl methyl sulphonyl fluoride (PMSF) and the $250 \mathrm{mmol} \mathrm{L}^{-1}$ of the inactivator ovalbumin (OVO). The residual activity of the alkaline proteases was determined with the technique described by Kunitz (1947) and modified by Walter (1984) as previously described. In acid and alkaline activities, a control sample without inhibitor was used and the residual activity was expressed as a percentage, all tests were performed in triplicate.

Zymogram analyses. Electrophoretic analyses were performed with a Mini-PROTEAN 3 Cell (Bio-Rad) with four plates containing vertical gels $(8 \times 10 \times 0.075 \mathrm{~cm})$ with $10 \mathrm{ml}$ sample capacity per plate. For the analysis of stomach acid proteases, electrophoresis was run under non-denaturing native condition (native-PAGE) using a continuous polyacrylamide gel $(10 \%)$ in Tris buffer $\left(25 \mathrm{mmol} \mathrm{L}^{-1}\right) \mathrm{y}$

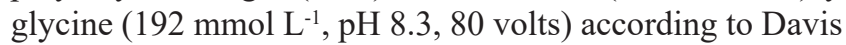
(1964). For the analysis of alkaline proteases, the plate was prepared by stacking a gel with $4 \%$ polyacrylamide (PAA) and resolving the gel with 10\% PAA. Electrophoresis was run under denaturalizing conditions (SDS-PAGE), with SDS in $0.1 \%$ Tris buffer $\left(25 \mathrm{mmol} \mathrm{L}^{-1}\right)$ and glycine $(192 \mathrm{mmol}$ $\mathrm{L}^{-1}, \mathrm{pH} 8.3,100$ volts), according to Laemmli (1970), and adapted by García-Carreño et al. (1993). The gels were treated to reveal proteases isoforms according to the procedure of Díaz-López et al. (1998), were washed and incubated for $30 \mathrm{~min}$ at $5^{\circ} \mathrm{C}$ in a $0.5 \%$ casein solution (Tris- $\mathrm{HCl} 100 \mathrm{mmol}$ $\mathrm{L}^{-1}$ buffer, $\mathrm{pH}$ 9), then gels were incubated for $90 \mathrm{~min}$ in the same solution composition at $37{ }^{\circ} \mathrm{C}$, and then washed and fixed in trichloroacetic acid (12\%) solution for $15 \mathrm{~min}$. After areas for detection of enzyme activity had been developed, they were stained according to Weber, Osborn (1969), using a $0.1 \%$ Coomassie brilliant blue R-250 solution, while distaining was carried out in a 35:10:55 solution of methanol-acetic acid-water. Clear zones revealed the activity of proteases within a few minutes, although well-defined zones were obtained after 2-4 h. 
Electrophoresis was complemented with the use of specific inhibitors previously mentioned, according to the method described by Dunn (1989). The enzymatic extracts were pre-incubated for $1 \mathrm{~h}$ with every inhibitor $(1: 1 \mathrm{v} / \mathrm{v})$ and were applied to each SDS-PAGE $(5 \mu 1$ per well). A molecular weight marker was used: BM523 (molecular weight marker Bio Basic Inc; rabbit phosphorylase B $96.7 \mathrm{kDa}$, bovine serum albumin $66.2 \mathrm{kDa}$, ovalbumin $45 \mathrm{kDa}$, carbon anhydrase $31.0 \mathrm{kDa}$, trypsin soybean inhibitor $21.5 \mathrm{kDa}$ and lysozyme $14.4 \mathrm{kDa}$ ). The relative electromobility (Rf) was calculated for the zymograms according Igbokwe, Downe (1978). Molecular weight (MW) of each band in the SDS-Zymogram (alkaline proteases) was calculated using a linearly adjusted relationship between the Rf and $\log 10$ of the MW protein markers, using the Quality One version 4.6.5 (Hercules, CA) software program.

Statistic analysis. Data did not comply with the assumptions of normality and homoscedasticity, therefore, a nonparametric variance analysis (Kruskal-Wallis) was used to compare the residual activity between $\mathrm{pH}$, and $\mathrm{Chi}^{2}$ test from the arcsine transformation was used to analyse temperature stability and the percentage of residual activity in the inhibition tests of acidic and alkaline proteases. A non-parametric Nemenyi test was used when significant differences were detected. All tests were carried out with Statistica v 7.0 software (StatSoft, Tulsa, OK, EU).

\section{Results}

The proteolytic activity level of the digestive tract of juvenile sheepshead is shown in Tab. 1 . The activity of the acid proteases $\left(2.39 \pm 0.02 \mathrm{U} \mathrm{mg}\right.$ protein $\left.^{-1}\right)$ was higher than alkaline protease activity $\left(1.6 \pm 0.1 \mathrm{U} \mathrm{mg} \mathrm{protein}^{-1}\right)$, as well as the activity of other alkaline endopeptidase enzymes such as trypsin and chymotrypsin $(0.45 \pm 0.02$ and $0.65 \pm 0.1 \mathrm{U}$ $\mathrm{mg}$ protein $^{-1}$, respectively) and exopeptidases leucin aminopeptidase and carboxypeptidase $\mathrm{A}(0.007 \pm 0.001$ and 0.5 $\pm 0.1 \mathrm{U} \mathrm{mg} \mathrm{protein}^{-1}$, respectively).

Tab. 1. Specific activity levels of digestive proteases (mean $\pm \mathrm{SD}, \mathrm{n}=3$ ) in enzymatic extracts of stomach and intestine from juveniles of Archosargus probatocephalus.

\begin{tabular}{lc}
\hline \multicolumn{1}{c}{ Enzyme } & Specific activity $\left(\mathrm{U} \mathrm{mg}\right.$ protein $\left.^{-1}\right)$ \\
\hline Acid proteases & $2.39 \pm 0.02$ \\
Alkaline proteases & $1.6 \pm 0.1$ \\
Trypsin & $0.45 \pm 0.02$ \\
Chymotrypsin & $0.64 \pm 0.1$ \\
Carboxypeptidase A & $0.5 \pm 0.1$ \\
Leucine aminopeptidase & $0.007 \pm 0.001$ \\
\hline
\end{tabular}

The optimum $\mathrm{pH}$ for acid protease activity was 2 (Fig. 1a). The stability to $\mathrm{pH}$ changes was greater between $\mathrm{pH}$ 2 and 4, compared with the stability observed at the other $\mathrm{pH}$ values (Fig. 1b). Residual activity of acid proteases was maintained around $100 \%$ in $\mathrm{pH} 2$ and 4 until 90 min of preincubation, while the rest of the pHs decreased after $30 \mathrm{~min}$ of preincubation. For alkaline protease activity the optimum $\mathrm{pH}$ was observed to be 9 (Fig. 1c), while greater stability to changes in $\mathrm{pH}$ was observed at $\mathrm{pH} 10$, demonstrating a significant difference $(\mathrm{P}<0.05)$ when compared to other $\mathrm{pHs}$, reaching above $130 \%$ residual activity until the time of 90 minutes of preincubation. Likewise, for $\mathrm{pH} 8,100 \%$ activity was detected at up to 90 minutes of preincubation (Fig. 1d).

The optimum temperature of acid protease activity was $45^{\circ} \mathrm{C}$ (Fig. 2a). Likewise, greater stability was recorded at $25{ }^{\circ} \mathrm{C}$ (significant difference, $\mathrm{P}<0.05$ ), with $100 \%$ activity until $90 \mathrm{~min}$ of preincubation. The stability of acid proteases was reduced to $90 \%$ at temperatures of 55 and $65{ }^{\circ} \mathrm{C}$ after 30 minutes of preincubation (Fig. 2b). In contrast, the optimum temperature of alkaline protease activity was 55 ${ }^{\circ} \mathrm{C}$ (Fig. 2c), where greater stability was recorded between 25 and $45{ }^{\circ} \mathrm{C}$, showing an activity of $115 \%$ at up to $90 \mathrm{~min}$ of preincubation. Finally, the stability of alkaline protease activity was reduced by $90 \%$ at $65{ }^{\circ} \mathrm{C}$ after 30 minutes of preincubation (Fig. 2d).

The analysis with inhibitors indicates that acidic protease activity was inhibited $79 \%$ by Pepstatin A. Alkaline proteases activity showed that $30 \%$ of the total activity was inhibited by TPCK, while TLCK inhibited $75 \%$. Ovalbumin inactive $61 \%$, SBTI inhibited $70 \%$ and with PMSF inhibited $45 \%$. Chelants such as PHEN and EDTA inhibited the $23 \%$ and $7 \%$, respectively (Fig. 3). The electrophoresis under native-PAGE conditions revealed a single acid protease with relative electromobility (Rf) of 0.49 , this band was completely inhibited by Pepstatin A (Fig. 4). In the SDS-PAGE electrophoresis analysis of alkaline proteases without inhibitor revealed four bands with molecular weights ranging from 21.2 to $51.3 \mathrm{kDa}$ (Fig. 5). Ovalbumin inhibited the band of $51.3 \mathrm{kDa}$, and SBTI inhibited two bands (21.2 and $27.8 \mathrm{kDa}$ ), while TLCK inhibited all bands. By the other side, presence of PMSF, TPCK, PHEN and EDTA did not inhibit any active band.

\section{Discussion}

Our results show that $A$. probatocephalus juveniles display a higher activity of acid proteases compared to alkaline proteases. These results indicate that juveniles of this species have carnivorous habits, similar to other fish such as $S$. aurata (Alarcón et al., 2001), T. thynnus (Essed et al., 2002), Scleropages formosus (Natalia et al., 2004), Scophthalmus maximus (Linnaeus, 1758) (Wang et al., 2006), Atractosteus tropicus Gill, 1863 (Guerrero-Zárate et al., 2014), common dentex Dentex dentex (Linnaeus, 1758) (Alarcón et al., 1998), S. senegalensis (Saénz -de Rodrigáñez et al., 2005) and C. undecimalis (Concha-Frias et al., 2016), which exhibit high pepsin-like activity in the stomach, and a lower activity of alkaline proteases detected in the intestine, where the final part of the hydrolysis process takes place, releasing peptides and amino acids, which are subsequently absorbed by the enterocytes (Yúfera, Darias, 2007). 

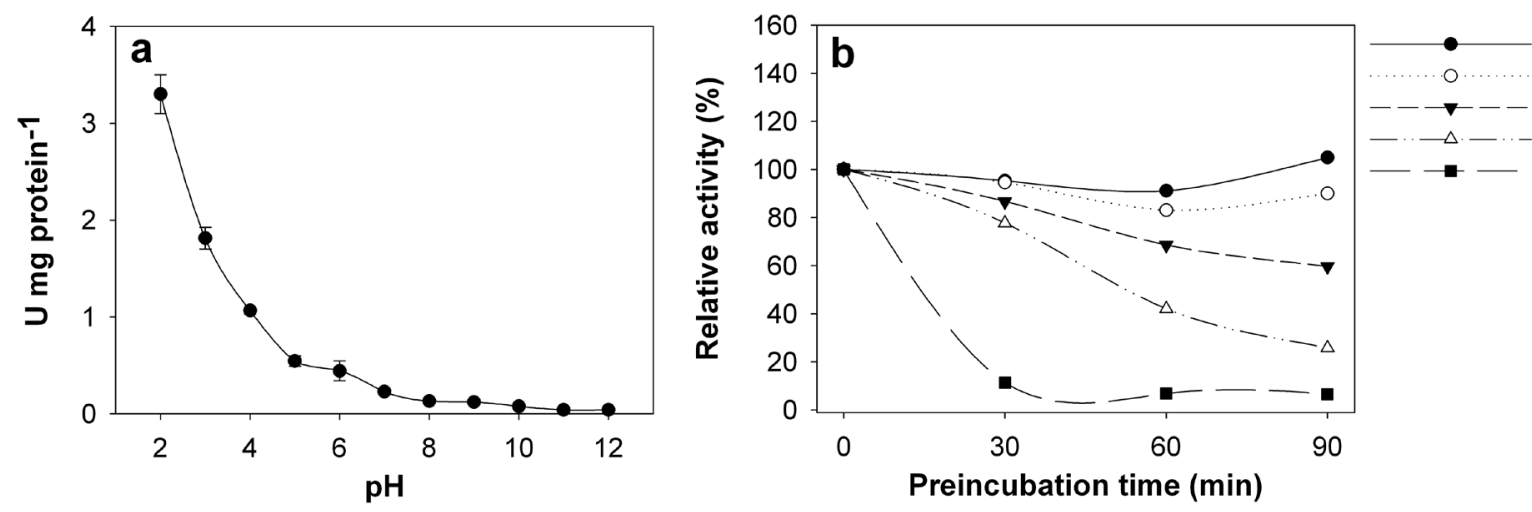

$\mathrm{pH} 2$

$\mathrm{pH} 4$

$\mathrm{pH} 6$

$\mathrm{pH} 8$
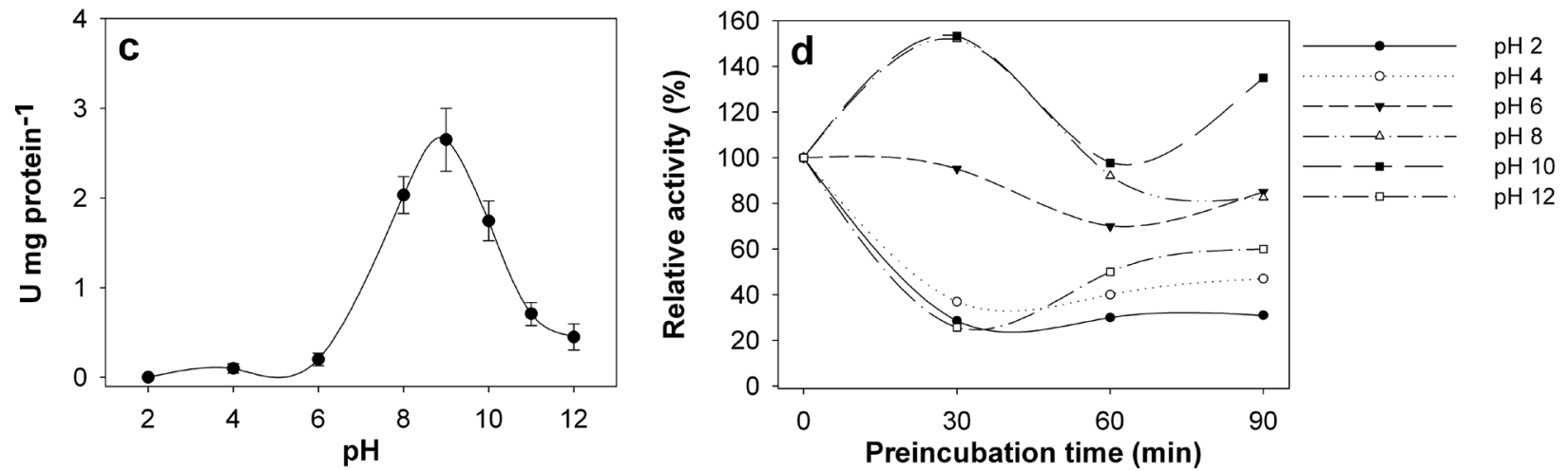

Fig. 1. $\mathrm{pH}$ effect on digestive proteases of juvenile sheepshead Archosargus probatocephalus: (a) optimal pH of acidic proteases, (b) stability of acidic proteases, (c) optimal pH of alkaline proteases, (d) stability of alkaline proteases.
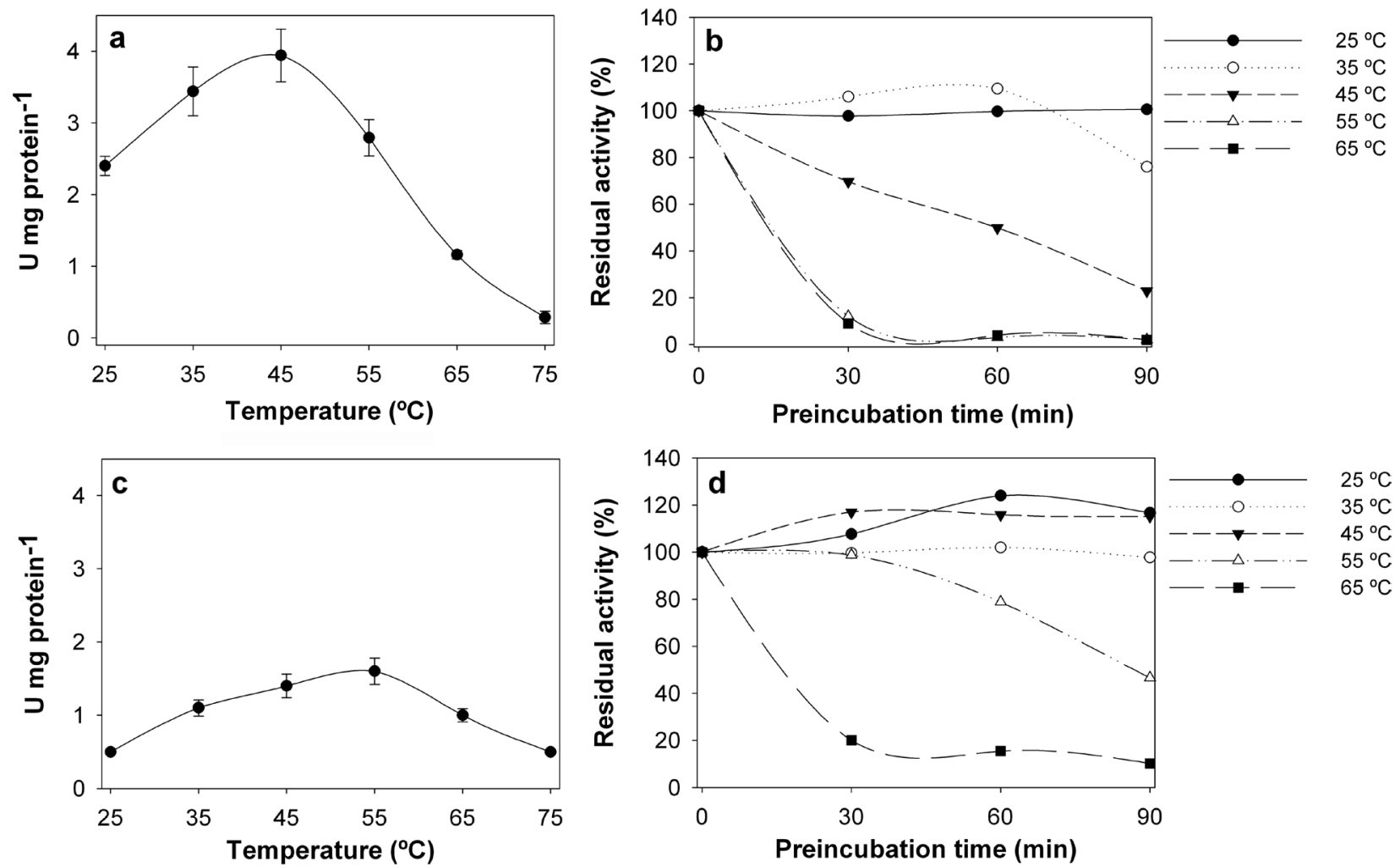

Fig. 2. Temperature effect on digestive proteases of juvenile of sheepshead Archosargus probatocephalus: (a) optimal temperature of acidic proteases, (b) temperature stability of acidic proteases, (c) optimal temperature of alkaline proteases, (d) temperature stability of alkaline proteases. 


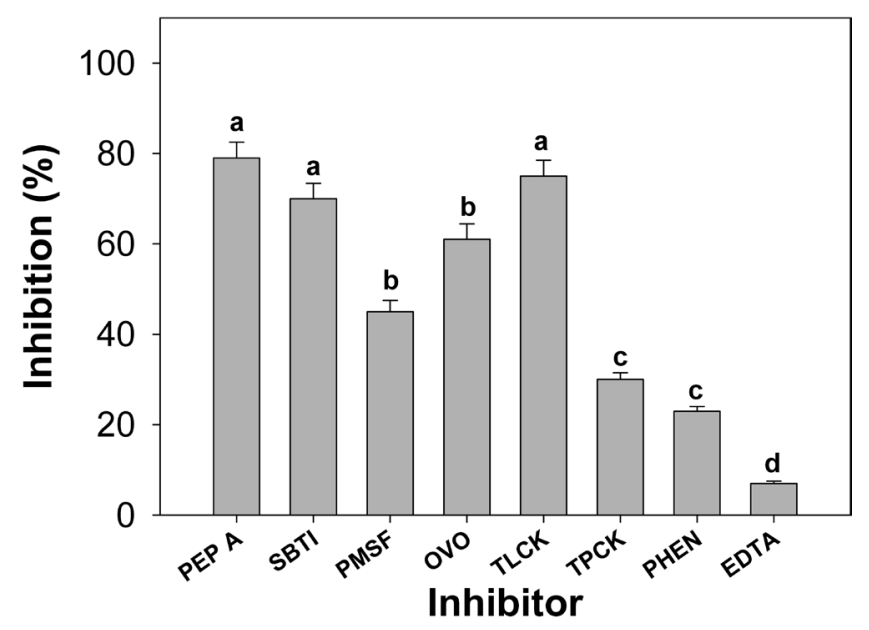

Fig. 3. Effect on the reduction of digestive protease activity in enzymatic extracts of Archosargus probatocephalus juveniles by different inhibitors: Pepsin inhibitor: Pepstatin A (Pep A), Serin protease inhibitors and inactivator: soybean trypsin inhibitor (SBTI), phenyl methyl sulphonyl fluoride (PMSF), and ovalbumin (OVO), Trypsin inhibitor: tosyl-lysyl-chloromethyl ketone (TLCK), Chymotrypsin inhibitor: tosyl-phenylanyl-chloromethyl ketone (TPCK), Metallo- proteases inhibitor: phenanthroline (PHEN), ethyldiamine tetra-acetic acid (EDTA). The values are expressed as percentage of inhibition against a control assay without inhibitor, the bars indicate SD values, (Nemenyi, $\mathrm{P}<0.05$ ).

In this sense, studies of the stomach content of sheepshead indicate an omnivorous trophic strategy with a tendency for carnivory, an unusual behavior among sparids, which tend to be carnivores such as $S$. auratus and D. dentex (Alarcón et al., 1998; Cutwa, Turingan, 2000; Castillo-Rivera et al., 2007). It is known that some species transition from a carnivorous habit to an omnivorous or herbivorous habit during their development, which is often the case in sheepshead whose diet consists predominantly of invertebrates, mainly crustaceans and plants, during adulthood (Castillo-Rivera et al., 2007). Thus, juveniles older than $50 \mathrm{~mm}$ long consume hard-shell organisms such as bivalve mollusks, brachyurans, echinoderms, barnacles, and opportunistically small fish (Jennings, 1985), while adults feed mainly on algae and invertebrates. In the same context, this species consumes crustaceans more efficiently than algae and grass (Jobling, 1995), although the abundant availability and low energy cost of location and capture of plants may favor an omnivorous strategy, rather than a strictly carnivorous strategy (Montgomery, Targett, 1992).

This capacity has been observed in other studies conducted in this species, where the ability to consume plant material can be related to the presence of morphological adaptations in the dental structure and intestine length. Thus, Castillo-Rivera et al. (2007) report that the species shows adaptations characteristic of the trophic morphology, exhibiting a short snout, inferior almost horizontal mouth, in

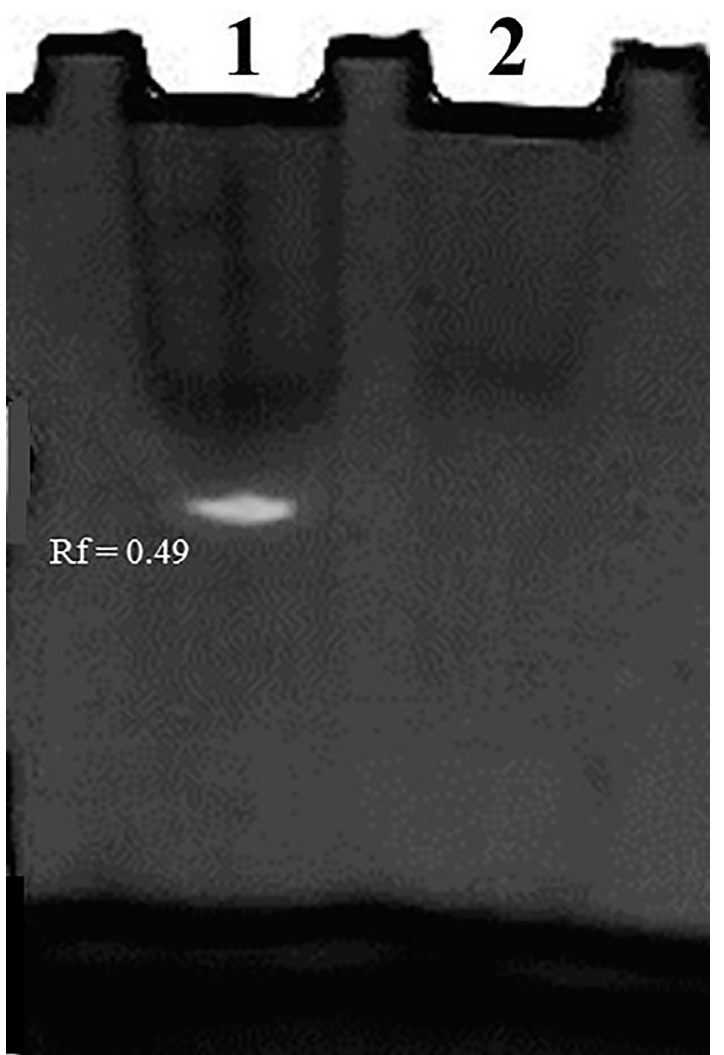

Fig. 4. Zymogram of acid proteases from enzyme stomach extracts of Archosargus probatocephalus. Crude enzymatic extract (1), crude enzymatic extract plus Pepstatin A (2).

addition to incisor teeth capable of cutting with a series of molars capable of crushing, which is typically observed in herbivores (Jobling, 1995; Moyle, Cech, 2000). However, the species shows a well-developed stomach in the form of a muscular sac, and the presence of pyloric caeca (on average 5.8), which apparently do not have modifications in other species of this family (Luczkovich, Stellwag, 1993) that serve to increase the surface area of digestion and absorption of certain nutrients (Buddington, Diamond, 1986). This species displays an average relative intestinal length of $129 \%$, and is considered as an omnivorous and diurnal predator species (Matlock, García, 1983; López-López et al., 1991; Castillo-Rivera et al., 2007). Considering the above, in the present study organisms of $100 \mathrm{~g}$ were used, during a stage in which this species has a carnivorous tendency according to previous reports, which explains the high activity values of acidic proteases compared to alkaline proteases.

In the present study, it was observed that A. probatocephalus has a stomach with a defined structure, which secretes acidic proteases that require a $\mathrm{pH}$ of 2 for maximum activity, similar to that reported for other fishes of the Sparidae family such as; $S$. aurata, D. dentex (Alarcón et al., 1998) and sharpsnout seabream [Diplodus puntazzo (Walbaum 1792)] (Tramati et al., 2005). The $\mathrm{pH}$ value where an optimal activity is found is related to the $\mathrm{pH}$ where the active center of the enzyme presents an adequate ionic 


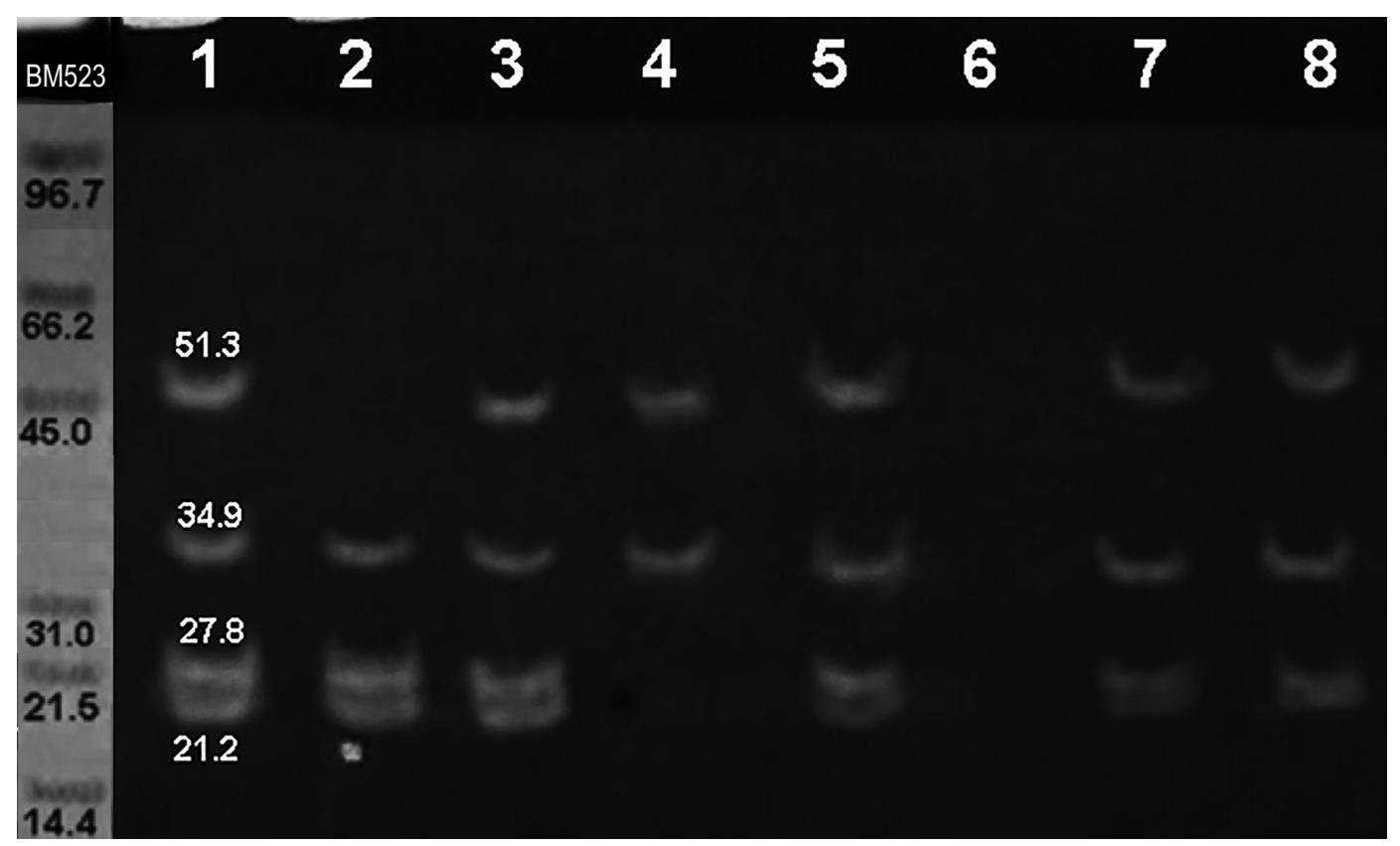

Fig. 5. SDS-PAGE electrophoresis analysis of alkaline digestive proteases of Archosargus probatocephalus: BM523 (molecular weight marker Bio Basic Inc; rabbit phosphorylase B $96.7 \mathrm{kDa}$, bovine serum albumin $66.2 \mathrm{kDa}$, ovalbumin $45 \mathrm{kDa}$, carbonic anhydrase $31.0 \mathrm{kDa}$ soybean trypsin inhibitor $21.5 \mathrm{kDa}$ and lysozyme $14.4 \mathrm{kDa}$ ), Control (1); inhibitors: OVO (2), PMSF (3), SBT1 (4), TPCK (5), TLCK (6), PHEN (7) and EDTA (8).

conformation to carry out the catalysis with great efficiency (Álvarez-González et al., 2010). In this sense, the optimal activity found for acid proteases was $\mathrm{pH} 2$, which coincides with reports of other species such as Siluru glanis (Jonas et al., 1983), S. aurata, D. dentex (Alarcón et al., 1998), Brycon orbignyanus (Valenciennes, 1850) (García-Carreño et al., 2002), Symphysodon aequifasciatus Pellegrin, 1904 (Chong et al., 2002), S. formosus (Natalia et al., 2004), D. puntazzo (Tramati et al., 2005), S. senegalensis (Sáenz -de Rodrigáñez et al., 2005), S. maximus (Wang et al., 2006), African coelacanth Latimeria chalumnae Smith, 1939 (Tanji et al., 2007), threadfin bream Nemipterus spp. (Nalinanon et al., 2008), T. alalunga and skipjack tuna Katsuwonus pelamis (Linnaeus, 1758) (Nalinanon et al., 2010a, b) and $C$. undecimalis (Concha-Frias et al., 2016).

On the other hand, the alkaline proteases of sheepshead show an optimum $\mathrm{pH}$ of 9 , which is common in many species, with maximum activity occurring between $\mathrm{pH} 9$ and 10, as reported in Brycon orbignyanus (García-Carreño et al., 2002), Labeo rohita (Hamilton, 1822) and H. molitrix (Kumar et al., 2007), T. orientalis (Matus-De la Parra et al., 2007), grass carp Ctenopharyngodon idella (Valenciennes, 1844) (Liu et al., 2008), hybrid juvenile tilapia Oreochromis niloticus (Linnaeus, 1758) x Oreochromis aureus (Steindachner, 1864) (Jun-Sheng et al., 2006), D. puntazzo (Tramati et al., 2005), C. urophthalmus (Cuenca-Soria et al., 2014) and Amphilophus trimaculatus (Günther, 1867) (Toledo-Solís et al., 2016). Nevertheless, species with more than one optimum $\mathrm{pH}$ value have been reported, such as C. undecimalis, showed optimal activity at pH 7 and 11 (Con-
cha-Frías et al., 2016) that can be attributed to the diversity of enzymes and isoforms present in the species (Alarcón et al., 1998). Although it should be mentioned that sheepshead presented only one optimum $\mathrm{pH}$, which indicates that the intestinal digestive proteases present in the species shows the same optimum $\mathrm{pH}$ value (Matus-De la Parra et al., 2007).

In $A$. probatocephalus, the acid proteases are stable at acid $\mathrm{pH}$ and their activity decreases as the environment becomes alkaline; while alkaline proteases are stable at alkaline $\mathrm{pH}$ and are resistant to slightly acid $\mathrm{pH}$, these conditions are similar to that reported in C. urophthalmus (Cuenca-Soria et al., 2014). However, in other fish with strictly carnivorous habits that lives marine habitat, acidic proteases are stable for a short time at alkaline $\mathrm{pH}$ as described for T. thynnus (Essed et al., 2002) and S. maximus (Wang et al., 2006). This has also been reported for freshwater carnivorous species such as A. tropicus (Guerrero-Zárate et al., 2014) and marine omnivorous species such as $S$. senegalensis (Sáenz -de Rodrigáñez et al., 2005). The fact that acidic proteases are resistant to alkaline $\mathrm{pH}$ allows acidic proteases to continue acting in the degradation of the food when get inside the intestine, until the media is alkalized, where alkaline proteases end the digestion procces. However, in A. probatocephalus, acid protease activity is lost at neutral and alkaline $\mathrm{pH}$, this process is not reflected, where the loss of activity is compensated by the hydrolysis of alkaline proteases that are active under acidic conditions and at the same time is compensated by the presence of the pyloric caeca, a large intestine and strong sphincters, which regulate the food transit, joined to the action of digestive hormones (such as cholecystokinin) 
that stimulate peristaltic movements, increasing the contact surface in the enzyme-substrate relationship (Salvensen, 1989; Simpson, 2000).

Accordantly, alkaline digestive proteases may act since food enters to the intestine, even at acid $\mathrm{pH}$. It is important to mention that, in general alkaline proteases are more stable at different $\mathrm{pH}$ levels, due to the presence of protease diversity (trypsin, chymotrypsin, aminopeptidase and carboxypeptidases) as demonstrated in the zymogram, when four bands, which increase the possibility of hydrolyzing food proteins across a wide $\mathrm{pH}$ range during variation (Alarcón et al., 1998). In contrast, most fish species present two or three pepsins with an optimum haemoglobin digestion between 2 and 4 (Klomklao, 2008). In this sense, Klomklao et al. (2007) reported the presence of pepsin A and pepsin B from giant grenadier [Albatrossia pectoralis (Gilbert, 1892)], Chiu, Pan (2006) report two pepsin isoforms (PI and PII), in juvenile and adult of Japanese eel (Anguilla japonica Temminck \& Schlegel, 1846) and Peña et al. $(2015,2017)$ report two pepsin isoforms in spotted rose snappers (L. guttatus). Therefore, isoforms of one-enzyme types present small functional differences that increase the effects of changes to structural configuration or denaturation and consequently generates a partial or total loss of the activity (Nalinanon et al., 2010b).

On the other hand, the optimum temperature in $A$. probatocephalus alkaline proteases is $10^{\circ} \mathrm{C}$ higher at the optimum temperature of the acid proteases and at the same time shows more thermostability. In general, this difference between the optimal temperatures of alkaline and acid proteases has been described in species such as T. thynnus (Essed et al., 2002), B. orbignyanus (García-Carreño et al., 2002) and C. trimaculatum (Toledo-Solís et al., 2016). The optimum temperature of acid proteases was observed as $45^{\circ} \mathrm{C}$, being similar to that reported for $S$. aurata (Alarcón et al., 1998) and $T$. orientalis (Matus-De la Parra et al., 2007), which shows a decrease in activity at temperatures from $55^{\circ} \mathrm{C}$, an effect related to the denaturation of pepsin (Nalinanon et al., 2008).

In contrast, alkaline proteases exhibit optimum activity at a temperature of $55^{\circ} \mathrm{C}$, which is similar to that found in S. aurata, D. dentex (Alarcón et al., 1998), spotted goatfish Pseudupeneus maculatus (Bloch, 1793) (Souza et al., 2007), parrotfish Sparisoma sp., traira Hoplias malabaricus (Bloch, 1794) (Alencar et al., 2003) and O. niloticus (Bezerra et al., 2005), which show an optimum temperature for alkaline proteases of between 50 and $55^{\circ} \mathrm{C}$, and presents more thermostability, while temperatures from $65^{\circ} \mathrm{C}$ only affect $80 \%$ of residual activity. However, the activity fall could be compensated by the increasing retention time of food in the digestive tract to perform proteins hydrolysis at lower temperatures than optimal (Alarcón et al., 1998; Uscanga et al., 2010). It should be mentioned that optimal temperature values and thermal stability of protease activities are only operational parameters of the enzymes, rather than results of physiological importance; which can be associated with the configuration of enzymes as well as the habitat, environment and genetic aspects of the species (Nalinanon et al., 2008).
The identification of the proteases that constitute acid digestion in sheepshead was evaluated with the use of Pepstatin A inhibitor, which showed a 79\% inhibition, a similar value to freshwater or omnivorous species with a carnivory tendency which has previously been reported in C. urophthalmus (Cuenca-Soria et al., 2014) and C. trimaculatum (Toledo-Solís et al., 2016) and lower than the percentage of inhibition found exclusively in carnivorous species such as $S$. maximus (Wang et al., 2006), mandarin fish (Siniperca chuatsi) (Zhou et al., 2008), skipjack tuna Katsuwonus pelamis (Nalinanon et al., 2010b) and C. undecimalis (Concha-Frias et al., 2016). Therefore, hydrolysis in acid conditions is in first term performed by presence of pepsin A type, with the possible presence of other pepsin isoforms as observed in species such as Japanese seabass Lateolabrax japonicus (Cuvier, 1828) (Cao et al., 2011), tropical gar A. tropicus (Guerrero-Zárate et al., 2014) and the sparids gilthead seabream S.aurata and common dentex D. dentex (Alarcón et al., 1998), among others already mentioned, where diverse types of pepsins were detected, which gives a high capacity to hydrolyze proteins in the stomach. The lower inhibition of pepsin in the stomach of $A$. probatocephalus could be related to the presence of other types of pepsin, since a high residual activity was observed at $\mathrm{pH} 4$ and showed a 79\% inhibition with Pepstatin A inhibitor. This was not revealed with the electrophoresis under native-PAGE conditions owing to a single active band with acid protease activity was found. Similar results were reported by Alvarez-González et al. (2010) in spotted sand bass Paralabrax maculatofasciatus (Steindachner, 1868). The band whith acid protease activity registered in the electrophoresis under native-PAGE conditions shows Rf of 0.49 , which compared to values recorded in other fish species such spotted sand bass $P$. maculatofasciatus with a $\mathrm{Rf}=0.75$ (Alvarez-González et al., 2010), spotted rose snappers L. guttatus with a Rfs of 0.71 and 0.77 (Peña et al., 2017) and the sparids gilthead seabream $S$. aurata and common dentex $D$. dentex of Rfs 0.81 and 0.66 (Alarcon et al., 1998), and similar was reported in tropical gar $A$. tropicus (Rfs 0.35 and 0.71 ).

On the other hand, the seven types of specific inhibitors for the alkaline proteases had a variable effect on the enzymatic activity. Of these, the group of serine proteases was inhibited by PMFS (45\%), OVO (61\%) and SBTI (70\%), these high inhibition values reveal the high activity of serine protease type enzymes in the intestine of sheepshead. This pattern of serine protease inhibition is similar to that reported in S. aequifasciata (Chong et al., 2002), T. thynnus (Essed et al., 2002), C. idella (Liu et al., 2008), C. trimaculatum (Toledo-Solís et al., 2015) and C. undecimalis (Concha-Frias et al., 2016). On the other hand, the group of metalloproteases exhibited a low inhibition PHEN (23\%), a similar value to that reported by Dimes, Haard (1994) in coho salmon [Oncorhynchus kisutch (Walbaum, 1792)] with EDTA (7\%). In contrast, the TPCK inhibited chymotrypsin-like activity by $30 \%$, similar to reports by Alarcón et al. (1998) in D. dentex and Chakrabarti et al. (2006) in L. rohita, whereas the TLCK 
inhibited trypsin-like activity by $75 \%$, indicate a greater proportion of trypsin compared to chymotrypsin, which is similar to previous observations in $B$. orbiginyanus (García-Carreño et al., 2002) and S. formosus (Natalia et al., 2004). Moreover, these data suggest that the inclusion of certain vegetable ingredients in balanced foods without leading to a subsequent reduction in digestive enzymatic activity and the digestibility of food (Essed et al., 2002). In this sense, the zymogram of alkaline proteases showed four bands with activity, which is lower than the number detected for other sparids such as $S$. aurata and D. dentex, where five and eight active proteases with caseinolitic activity were reported (Alarcón et al., 1998). Concurrently, other fish species have been reported with higher numbers of alkaline proteases, such as A. tropicus with the presence of five bands (Guerrero-Zárate et al., 2014) and $C$. undecimalis with seven isoforms (Concha-Frías et al., 2016).

The four bands registered confirm the predominating presence of the proteases trypsin, chymotrypsin and metallo-proteases, with molecular weights of $21.2 \mathrm{kDa}, 27.8$ $\mathrm{kDa}$ and $51.3 \mathrm{kDa}$, respectively. TLCK inhibited all bands recorded for trypsin, which was expected since TLCK has been identified as a trypsin inhibitor (García-Carreño, 1992), an observation previously reported by Lazo et al. (2007), whom indicated a molecular weight of 23 to $68 \mathrm{kDa}$ for trypsin in red drum Sciaenops ocellatus. It is likely that the band with a molecular weight of $34.9 \mathrm{kDa}$ was treated with chymotrypsin, a similar value to that reported by Souza et al. (2007) in P. maculatus. The inhibitors of serine proteases such as OVO inhibited the $51.3 \mathrm{kDa}$ band, SBT1 inhibited the 27.8 and $21.2 \mathrm{kDa}$ bands, yet PMSF did not inhibit any band, showing a high resistance of the intestinal digestive proteases of A. probatocephalus to inhibitors of trypsin-like or chymotrypsin-like enzymes, which is in agreement with previous reports in other studies of several species with omnivorous habits (Simpson, 2000; Castillo-Yáñez et al., 2005, 2006, 2009; Ben et al., 2011). The metallo-proteases generally have molecular weights between $45 \mathrm{kDa}$ and 97 $\mathrm{kDa}$ (Natalia et al., 2004), and are typically inhibited by the phenanthroline and chelator EDTA; however, in the present study EDTA did not inhibit any band which could indicate that trypsin and chymotrypsin do not require metal ions for their activation, as previously indicated by Cuenca-Soria et al. (2014).

In A. probatocephalus the presence of pepsin, serine proteases such as trypsin and chymotrypsin, and metalloproteases such as aminopeptidase and carboxipeptidase A suggest a protein digestion mechanism, similar to other fish and are involved in initiating hydrolysis, which also requires the activity of endopeptidases, followed by the action of exopeptidases, that are limited to degrading short peptide chains, releasing terminal aminoacids as indicated by Chong et al. (2002) and López-Ramírez et al. (2010). The digestive capacity in sheepshead is carried out by two possible factors: the presence of one pepsin isoform, as well as the characteristics of the intestinal digestive proteases, including their high re- sistance to $\mathrm{pH}$ conditions, temperature and inhibitors, representing food habits of carnivores with omnivore tendencies during this life stage.

\section{Acknowledgements}

The authors thank the National Technological Institute of Mexico for the financial support granted to carry out the research project entitled: Digestive Physiology of Archosargus probatocephalus larvae (Perciformes: Sparidae), code 5247.14.

\section{References}

Alarcón FJ, Díaz M, Moyano FJ, Abellán E. Characterization and functional properties of digestive proteases in two sparids; gilthead seabream (Sparus aurata) and common dentex (Dentex dentex). Fish Physiol Biochem.1998; 19(3):257-67.

Alarcón FJ, Moyano FJ, Díaz M. Use of SDS-page in the assessment of protein hydrolysis by fish digestive enzymes. Aquacult Int. 2001; 9(3):255-67.

Alencar BR, Biondi MM, Paiva MVL, Carvalho-Jr BL, Bezerra SR. Alkaline proteases from the digestive tract of four tropical fishes. Braz J Food Technol. 2003; 6(2):279-84.

Álvarez-González CA, Moyano-López FJ, Civera-Cercedo R, Carrasco-Chávez V, Ortiz-Galindo JL, Nolasco-Soria H, TovarRamírez D, Dumas S. Development of digestive enzyme activity in larvae of spotted sand bass Paralabrax maculatofasciatus II: electrophoretic analysis. Fish Physiol Biochem. 2010; 36(1):29-37.

Anson ML. The estimation of pepsin, trypsin, papain and cathepsin with hemoglobin. J Gen Physiol. 1938; 22(1):79-89.

Ben KH, Jellouli K, Souissi N, Ghorbel S, Barkia A, Nasri M. Purification and characterization of three trypsin isoforms from viscera of sardinelle (Sardinella aurita). Fish Physiol Biochem. 2011; 37(1):123-33.

Bezerra RS, Lins EJF, Alencar RB, Paiva PMG, Chaves MEC, Coelho LCBB, Carvalho-Jr LB. Alkaline proteinase from intestine of Nile tilapia (Oreochromis niloticus). Process Biochem. 2005; 40(5):1829-34.

Bradford MM. A rapid and sensitive method for the quantitation of microgram quantities of protein utilizing the principle of protein-dye binding. Anal Biochem. 1976; 72(1-2):248-54.

Buddington RK, Diamond JM. Aristotle revisited: The function of pyloric caeca in fish. Proc Nat Acad Sci. 1986; 83(20):8012-14.

Castillo-Rivera M, Zárate-Hernández R, Salgado-Ugarte IA. Hábitos de alimento de juveniles y adultos de Archosargus probatocephalus (Teleostei: Sparidae) en un estuario tropical de Veracruz. Hidrobiológica. 2007; 17(2):119-26.

Castillo-Yáñez FJ, Pacheco-Aguilar R, García-Carreño FL, Navarrete-Del Toro MA. Isolation and characterization of trypsin from pyloric caeca of Monterey sardine Sardinops sagax caerulea. Comp Biochem Physiol. 2005; 140(1):91-98.

Castillo-Yáñez FJ, Pacheco-Aguilar R, García-Carreño FL, Navarrete-Del Toro MA, Félix-López M. Purification and biochemical characterization of chymotrypsin from the viscera of Monterey sardine (Sardinops sagax caerulea). Food Chem. 2006; 99(2):252-59.

Castillo-Yáñez FJ, Pacheco-Aguilar R, Lugo-Sánchez ME, GarcíaSánchez G, Quintero-Reyes IE. Biochemical characterization of an isoform of chymotrypsin from the viscera of Monterey sardine (Sardinops sagax caerulea), and comparison with bovine chymotrypsin. Food Chem. 2006; 112(3):634-39. 
Cao MJ, Chen WQ, Du CH, Yoshida A, Lan WG, Liu GM, Su WJ. Pepsinogens and pepsins from Japanese seabass (Lateolabrax japonicus). Comp Biochem Physiol. 2011; 158(4):259-65.

Chiu ST, Pan BS. Digestive protease activities of juvenile and adult eel (Anguilla japonica) fed with floating feed. Aquaculture. 2006; 205(1-2):141-56.

Chong ASC, Hashim R, Chow-Yang L, Ali AB. Partial characterization and activities of proteases from the digestive tract of discus fish (Symphysodon aequifasciata). Aquaculture. 2002; 203(3-4):321-33.

Concha-Frías B, Alvarez-González CA, Gaxiola-Cortés MG, Silva-Arancibia AE, Toledo-Agüero PH, Martínez-García R, Camarillo-Coop S, Jiménez-Martínez LD, Arias-Moscoso JL. Partial Characterization of digestive proteases in the common snook Centropomus undecimalis. Int J Biol. 2016; 8(4):1-11.

Cuenca-Soria CA, Álvarez-González CA, Ortiz-Galindo JL, Nolasco-Soria H, Tovar-Ramírez D, Guerrero-Zárate R, Castillo-Domínnguez A, Perera-García MA, Hernández-Gómez R, Gisbert E. Partial characterisation of digestive proteases of the Mayan cichlid Cichlasoma urophthalmus. Fish Physiol Biochem. 2014; 40(3):689-99.

Cutwa M, Turingan RG. Intralocality variation in feeding biomechanics and prey use in $n$ Archosargus probatocephalus (Teleostei: Sparidae) with implications for the ecomorphology of fishes. Envir Biol Fish. 2000; 59(2):191-98.

Davis BJ. Disc electrophoresis. II. Method and application to human serum proteins. Ann N Y Acad Sci. 1964;121:404-27.

DelMar EG, Largman C, Brodrick JW, Geokas MC. A sensitive new substrate for chymotrypsin. Anal Biochem. 1979; 99(2):316-20.

Díaz-López M, Moyano-López FJ, Alarcón-López FJ, GarcíaCarreño FL, Navarrete del Toro MA. Characterization of fish acid proteases by substrate-gel electrophoresis. Comp Biochem Physiol. 1998; 121B:369-77.

Dimes LE, Haard NF. Estimation of protein digestibility - I. Development of an in vitro method for estimating protein digestibility in salmonids (Salmo gairdneri). Comp Biochem Physiol. 1994; 108A(2-3):349-62.

Dunn BM. Determination of protease mechanism. In: Beynon RJ, Bond JS (Eds), Proteolytic enzymes: A practical approach. Oxford; England: IRL Press; 1989, p.57-81.

Erlanger B, Kokowsky N, Cohen W. The preparation and properties of two new chromogenic substrates of trypsin. Arch Biochem Biophys. 1961; 95(2):271-78.

Essed Z, Fernández I, Alarcón FJ, Moyano FJ. Caracterización de la actividad proteasa digestiva de atún rojo Thunnus thynnus (Linnaeus, 1758). Bol Inst Esp Oceanogr. 2002; 18(1-4):99-107.

Falcón-Hidalgo B, Forrellat-Barrios A, Farnés OC, Hernández KU. Digestive enzymes of two freshwater fishes (Limia vittata and Gambusia punctata) with different dietary preferences at three developmental stages. Comp Biochem Physiol B, 2011; 158(2):136-41.

Figueira WF, Coleman FC. Comparing landing of United States recreational fishery sector. Bull Mar Sci. 2010; 86(3):499-514.

Folk JE, Schirmer EW. The porcine pancreatic carboxypeptidase A system. I. Three forms of the active enzyme. J Biol Chem. 1963; 238:3884-94.

García-Carreño FL. Protease inhibition in theory and practice. Biotech Education. 1992; 3:145-50.

García-Carreño FL, Dimes LE, Haard NF. Substrate-gel electrophoresis for composition and molecular weight of proteinases or proteinaceous protease inhibitors. Anal Biochem. 1993; 214(1):65-69.
García-Carreño LF, Albuquerque-Cavalcanti C, Navarrete del Toro AM, Zaniboni-Filho E. Digestive proteinases of Brycon orbignyanus (Characidae, Teleostei): characteristics and effects or protein quality. Comp Biochem Physiol. 2002; 132(2):343-52.

Gulf States Marine Fisheries Commission (GSMFC). The Sheephead Fishery of the Gulf of Mexico, United States: A Fisheries profile, by the Sheephead Technical Task Force. Edited S.J VanderKooy, Ocean Spring, Mississipi USA. 2006.

Guerrero-Zárate R, Alvarez-González CA, Olvera-Novoa MA, Perales-García N, Frías-Quintana CA, Martínez-García R, Contreras-Sánchez WM. Partial characterization of digestive proteases in tropical gar Atractosteus tropicus juveniles. Fish Physiol Biochem. 2014; 40(4):1021-29.

Igbokwe EC, Downe AER. Electrophoretic and histochemical comparison of the three strains of Aedes aegypti. Comparative Biochem and Physiol. 1978; 60B:131-36.

Jennings CA. Species profiles: life histories and environmental requirements of coastal fishes and invertebrates (Gulf of Mexico) - Sheepshead. U.S. Fish Wildl. Serv. Biol. Rpt. 1985; 82(11.29).

Jobling M. Environmental Biology of Fishes. Chapman Hall. Great Britain. 1995.

Jun-Sheng L, Jian-Lin L, Ting-Ting W. Ontogeny of protease, amylase and lipase in the alimentary tract of hybrid juvenile tilapia (Oreochromis niloticus x Oreochromis aureus). Fish Physiol Biochem. 2006; 32:295-303.

Klomklao S. Digestive proteinases from marine organisms and their applications. Songklanakarin J Sci Technol. 2008; 30(1):37-46.

Klomklao S, Kishimura H, Yabe M, Benjakul S. Purification and characterization of two pepsins from the stomach of pectoral rattail (Coryphaenoides pectoralis). Comp Biochem Physiol. 2007; 147B(4):682-89.

Kumar S, García-Carreño FL, Chakrabarti R, Navarrete del Toro MA, Córdova-Murueta JH. Digestive proteases of three carps Catla catla, Labeo rohita and Hypophthalmichthys molitrix: partial characterization and protein hydrolysis efficiency. Aquacult Nutr. 2007; 13(5):381-88.

Kunitz M. Crystalline soybean trypsin inhibitor: II. General properties. J Gen Physiol. 1947; 30(4):291-310.

Kuz'mina VV, Strel'nikova AP. Influence of diurnal rhythms of feeding during intestine total amylolytic activity and activity of alkaline phosphatase in juvenile fish. Inland Water Biol. 2008; 1(2):182-91.

Laemmli UK. Cleavage of structural proteins during the assembly of the head of bacteriophage T4. Nature. 1970; 227:680-85.

Lazo JP, Mendoza R, HoltGJ,Aguilera C,ArnoldCR. Characterization of digestive enzymes during larval development of red drum (Sciaenops ocellatus). Aquaculture. 2007; 265(1-4):194-205.

Liu ZY, Wang Z, Xu SY, Xu LN. Partial characterization and activity distribution of proteases along the intestine of grass carp, Ctenopharyngodon idella (Val.). Aquacult Nutr. 2008; 14(1):31-39.

López-López E, Salgado-Mejía M, Guzmán-Del Proo SA. Un análisis estacional de la ictiofauna de la laguna de Tampamachoco, Ver., y sus hábitos alimentarios. An Escuela Nac Cien Biol. 1991; 34:81-107.

López-Ramírez G, Cuenca-Soria CA, Álvarez-González CA, Tovar-Ramírez D, Ortíz-Galindo JL, Perales-Gracía N, Marquez-Couturier G, Arias-Rodríguez L, Indy JR, ContrerasSánchez WM, Gilbert E, Moyano FJ. Development of digestive enzymes in larvae of Mayan cichlid Cichlasoma urophthalmus. Fish Physiol Biochem. 2010; 37(1):197-208.

Luczkovich JJ, Stellwag EJ. Isolation of cellulolytic microbes from the intestinal tract of the pinfish, Lagodon rhomboides: Size- 
related changes in diet and microbial abundance. Mar Biol. 1993; 116(3):381-88.

Maroux S, Louvard D, Baratti J. The aminopeptidase from hogintestinal brush border. Biochim Bioph Acta. 1973; 321(1):28295.

Matlock GC, García MA. Stomach contents of selected fishes from Texas bays. Contri Mar Sci. 1983; 26:95-110.

Matus-De la Parra A, Rosas A, Lazo JP, Viana MT. Partial characterization of the digestive enzymes of Pacific bluefin tuna Thunnus orientalis under culture conditions. Fish Physiol Biochem. 2007; 33(3):223-31.

McDonough CJ, Wenner CA, Roumillat WA. Age, growth and reproduction of sheepshead in South Carolina, EU. Mar Coast Fisher. 2011; 3(1):366-82.

Montgomery JLM, Targett TE. The nutritional role of seagrass in the diet of the omnivorous pinfish Lagodon rhomboides (L.). J Exp Mar Bio Ecol. 1992; 158(1):37-57.

Moyle PB, Cech JJ. Fishes: An Introduction to Ichthyology. 4th Ed. Prentice Hall. USA; 2000.

Nalinanon S, Benjakul S, Visessanguan W, Kishimura H. Tuna Pepsin: Characteristics and its use for collagen extraction from the skin of threadfin bream (Nemipterus spp.). J Food Sci. 2008; 73(5):C413-19.

Nalinanon S, Benjakul S, Kishimura H. Biochemical properties of pepsinogen and pepsin from the stomach of albacore tuna (Thunnus alalunga). Food Chem. 2010a; 121(1):49-55.

Nalinanon S, Benjakul S, Kishimura H. Purifcation and biochemical properties of pepsins from the stomach of skipjack tuna (Katsuwonus pelamis). Eur Food Res Technol. 2010b; 231:259-69.

Natalia Y, Hashim R, Ali A, Chong A. Characterization of digestive enzymes in a carnivorous ornamental fish, the Asian bony tongue Scleropages formosus (Osteoglossidae). Aquaculture. 2004; 233(1-4):305-20.

Olsson C, Holmgren S. The control of gut motility. Comp Biochem Physiol. 2001; 128A(3):481-503.

Pattillo ME, Czapla TE, Nelson DM, Monaco ME. Distribution and abundance of fishes and invertebrates in Gulf of Mexico estuaries. Volume II: Species life history summaries. ELMR Rep. No. 11. NOAA/NOS Strategic Environmental Assessments Division, Silver Spring, USA; 1997.

Peña E, Hernández C, Álvarez-González CA, Ibarra-Castro L, Puello-Cruz A, Hardy RW. Comparative characterization of protease activity in cultured spotted rose snapper juveniles (Lutjanus guttatus). Lat Am J Aquat Res. 2015; 43(4):641-50.

Peña E, Hernández C, Ibarra-Castro L, Álvarez-González CA. In vitro protein digestibility of different grow-out stages of spotted rose snapper (Lutjanus guttatus, Steindachner, 1869). Aquacult Nutr. 2017; 23(6):1204-15.

RNIIPA. Red Nacional de Información e Investigación en pesca y acuacultura, Región III Golfo de México Norte, https://www. inapesca.gob.mx. Date of consultation 14 August 2017; 2012.

Sáenz-de Rodrigáñez M, Alarcón FJ, Martínez MI, Ruiz F, Díaz M, Moyano FJ. Caracterización de las proteasas digestivas del lenguado senegalés Solea senegalensis Kaup, 1858. Bol Inst Esp Oceanogr. 2005; 21(1-4):95-104.

Salvensen G, Nagase H. Inhibition of proteolytic enzymes. In: Beynon R, Bond JS (Eds). Proteolytic enzymes. IRL Press Oxford. UK; 1989. p.83-104.

Scocco P, Menghi G, Ceccarelli P. Histochemical differentiation of glycoconjugantes occurring in the tilapia intestine. J Fish Biol. 1997; 51:848-57.

Simpson BK. Digestive Proteases from Marine Animals. In: Haard
NF, Simpson BK (Eds). Seafood Enzymes. Marcel Dekker, New York, NY; 2000. p.191-213.

Souza AAG, Amaral IPG, Espírito Santo AR, Carvalho Jr. LB, Bezerra RS. Trypsin-like enzyme from intestine and pyloric caeca of spotted goatfish (Pseudupeneus maculatus). Food Chem. 2007; 100(4):1429-34.

Stauffer C. Enzyme assays for food scientists. Van Nostand Reinhold/AVI. New York; USA; 1989.

Tanji M, Yakabe E, Kageyama T, Yokobori S, Ichinose M, Miki $\mathrm{K}$, Ito H, Takahashi K. Purification and characterization of pepsinogens from the gastric mucosa of African coelacanth, Latimeria chalumnae, and properties of the major pepsins. Comp Biochem Physiol. 2007; 146B(3):412-20.

Toledo-Solís FJ, Márquez-Couturier G, Uscanga-Martínez A, Guerrero-Zárate R, Perales-García N, Contreras WM, CamarilloCoop S, Álvarez-González CA. Partial charaterization of digestive proteases of the three-spot cichlid Cichlasoma trimaculatum (Günter, 1867). Aquac Nutr. 2016; 22(6):1230-38.

Tramati C, Savona B, Mazzola A. A study of the pattern of digestive enzymes in Diplodus puntazzo (Cetti, 1777) (Osteichthyes, Sparidae): evidence for the definition of nutritional protocols. Aquacul Int. 2005; 13(1-2):89-95.

Tucker JW Jr. Marine fish culture. Kluwer Academic Publishers, Massachusetts, USA; 1998.

Tucker JW Jr. Sheepshead, a potential American sea bream for farming. World Aquacul Mag. 2004; 35(3):48-49.

Eroldogan OT, Suzer C, Tasbozan O, Tabakoglu S. The effect of rate-restricted feeding regimes in cycles on digestive enzymes of gilthead sea bream, Sparus aurata. Turkish J Fish Aquat Sci. 2008; 8:49-54.

Unajak S, Meesawat P, Paemanee A, Areechon N, Engkagul A, Kovitvadhi U, Kovitvadhi S, Rungruangsak-Torrissen $\mathrm{K}$, Choowongkomon K. Characterization of thermostable trypsin and determination of trypsin isozymes from intestine of Nile tilapia (Oreochromis niloticus L). Food Chem. 2012;134(3):1533-41.

Uscanga A, Moyano FJ, Álvarez-González CA. Assessment of enzymatic efficiency on protein digestion in the tilapia Oreochromis niloticus. Fish Physiol Biochem. 2010; 36(4):1079-85.

Walter HE. Proteinases: methods with hemoglobin, casein and azocoll as substrates. In: Bergmeyer HJ (Ed) Methods of enzymatic analysis, vol V. Verlag Chemie, Weinham; 1984. p. $270-77$.

Wang H, Wang Y, Wang Q, Xue C, Sun M. Purification and characterization of stomach protease from the turbot (Scophthalmus maximus L.). Fish Physiol Biochem. 2006; 32(2):179-88.

Weber K, Osborn M. The reliability of molecular weight determinations by dodecyl sulfate polyacrylamide gel electrophoresis. J Biol Chem. 1969; 244(16):4406-12.

Yúfera M, Darias MJ. Changes in the gastrointestinal $\mathrm{pH}$ from larvae to adult in Senegal sole (Solea senegalensis). Aquaculture. 2007; 267(1-4):94-99.

Zhou Q, Liu GM, Huang YY, Weng L, Hara K, Su WJ, Cao M-J. Pepsinogens and pepsins from mandarin fish (Siniperca chuatsi). J Agric Food Chem. 2008; 56(13):5401-06.

Submitted February 22, 2018

Accepted July 23, 2018 by Bernardo Baldisserotto 